原著

\title{
44
}

\section{四肢切斷方法及び術後治療上實際醫家の 注意すべき事項に就て}

\author{
東京市外吉祥寺 \\ 醫學博士 鈴 木 諒 爾
}

四肢切斷に際し，骨斷端住約 $2-3 \mathrm{~cm}$ 亿互. り骨膜及び骨路內骨膜を除去するブンゲ氏の 方法が現今一般に行はれ，他の方法は特別の 場合の外，殆ど行はれないことに略将一致を 見て居る㥞だが，皮辨處置の狀況を觀るに實 際は，マチマチで，治涾後斷端か醜形を呈す るものがかなり多く，從て不整な洀痕部に垢 や汗がたまり，不潔になり易いとか，或は其 の結果多少なりとも糜欄し易いとか，不愉快 なことを見ることが相當多い樣に見受けられ ๖. 其の原因は，多くは手術時の注:意周到な らざるととと，又術後縱ひ軣度なりとも一部

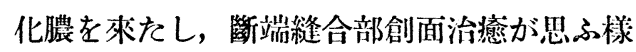
な形にならない爲めだと考へられる。而して 此化膿の原因は, 切呦端止血の際創面を度及

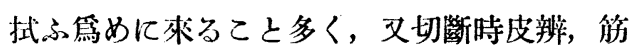
肉，筋膜の處置が不用意，不充分な爲め，術 後の實質性出血乃至體液渗出停溜のために起 ることが多い栐儿思はれる。

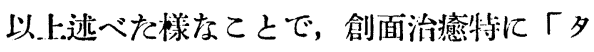
ンポン・ガーゼ」を施した所は治痖する迄相當
長い時日を要するものが多く，從て義肢を裝 用する時期束掘れる等のてとがあるので，私 共は之等の缺點を除きたいと思ひ，大正12年 から次の方法をとりました所，創面は大抵 2 週間，長くとも2 週間本で完全治瘾し，斷端 整ひ，義肢裝用早期適合する㥞な結果を得 たから，御參考迄住記载する次第である.

\section{術時の注菁}

1）ェスマル七氏止血帶の使朋法.

皮切を加一る前上り施し，手術終り皮属綘 合「タンポン」を施し，繃帶を終る迄，終始一 貫此血帶を掛け置くこと，從來多くは斷端血 管の紹禁を終れば，一旦柏血帶を取り出血の 模梯を觀，更に止血縫合する者多數なりしも， 斯くすれば實筫州血多く度々倽面を拭ふに上 り粆々もすれば化膿の惧なしとせず。

エスマルヒ此血帶を掛けたる儘几て主なる

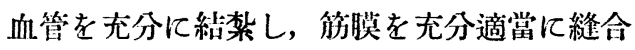
せば, 後出血の惧全然沶をより, 皮辫綘合, 繃帶施行後, 始めて止血帶を取除くことによ 
り，手術時間も短い，清潔に簡單に行はる.

2）皮辨の取り方，皮切，筋膜，筋肉の切 斷法, 及び出來るだけ皮辨と筋膜とを剥離せ ざる樣努むるてと.

皮辨の取り方：一伸展側の皮辨は大きく廣 く長く, 屈曲側の方は小さく狹く短かく取る てと.

此方法は成書に示めさるる通りなるも，實 際問題としては從來, 術者がまちまちで幐手 に內外側にとり, 特に下腿, 前膊等に於ては 兩骨斷端の部に於て陷山醜形庩痕を形成し， 義肢裝用に不便なものも屡々見受けられる。

筋膜, 跭肉の切斷方法: 一筋膜は皮切之全 く一致，同一の所に行ひ，皮膚之総朕とは出

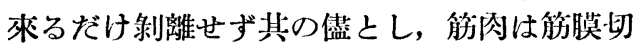
斷部より，骨に對し（術後の斷端形に充分の 考虑を拂ひつつ）周圍より少しく斜めに上方 に向て切斷す, (此際の裝作には切斷つは不便 なり),之により骨は切斷すべき部に於て露出 するを以て装作击だ都合よし。

3）骨の切斷方法.

一般成書の示めす所と同㥞なるも，只下腿 に於ては, 切絁後更に脛骨の前面を前上方上 り後下方に斜めに適䔰に鋸桓（場合により骨 䯣腔露出するも美支なし）整形することによ り, 術時軟部の縫合にも便にして日, 術後骨 斷端の皮下に婴出し皮虙を損傷し易きを避 け，早期義肢裝朋に適合せしむることを得.

4) 筋膜縫合.

骨切斷, 神經及び血管の處置に際し, 筋膜 と皮膚との剩離を出來るだけ避け，出來得れ ば全然刢離せずに行ひ，觔膜縫合の際始めて 皮膚と 2-3 cm 位の程度に止め洜離し充分筋
膜を周圍より引きよせ，將來貽るべき斷端形 を考慮しつつ縓絡縫合す, (皮膚も同時により 來る）之により實質性出血は全く停止す. 此 際には，必らず絹絲を艄ひ，腸線を用ひざる を要す, 腸線は縱ひ，藥品硬化せる太きもの を用ひても, 笳膜瘾着前, 術後 1-2 週間にて 吸收せられ，患者睡眠中等不用意の際笳肉收 縮の爲め, 筋膜縫合部多開し, 斷端組織間出 血，既に㴰合せる皮虐創面を破り出血を來た すことあり．特に年少者乃至青壯年に於て又 術前榮養衰へしもの特に關節結核, 肉腫等の 患者に於ては術洔用ひし腸線の吸收意外に早 く, 大正 14 年余等海軍々醫學校敎官勤務中, 築地病院に於て，數例の.上.述不快なる事實を 經驗せるてとあり，依て爾來此縫合には必ら ず絹禾を用ひたるに，上述不快なる例には全 然遭遇せることなし。

5) 皮辨縫合.

筩膜縫合により，皮䇐は創面周圍に近づき 來るにより，大小兩皮辨を，紐心の注意を以 てょく適合, 形を保たしむる樣縫合し, 內外 网側適當をる部に「タンポン・ガーゼ」を置く。 之により皮虞縫合部は, 筋膜縫合部に對し, 大抵 $1 \mathrm{~cm}$ 程屈曲側に偏する栐になり，皮辨と 㥐膜との剩離少きにより，斷端皮膚の榮養状 態は佳良にして, 適紧に㳊張し, 美しき健康 色を保ち, 治癒も早く且治癒後の形好よく整 ひ，皮下組織との䄖着も少くょく移動す.

6）繃帶方法.

繃帶洔, 使用する裝創材料師ち「ガーゼ」は 勿論綿花繃帶等は悉く隇菌せる物を使用す。 先づ「タンポン」部に小なる「ガーゼ」を置き， 夫れより創面に「四ツ折ガーゼ」老規則正しく 
並置し，更に资を重社適當の厚さを保たし め, 次に四折ガーゼ」をひろげ，前に貼せる 「ガーゼ」を充分に被包し，更に其の「ガーゼ」 より縱橫共大なる綿花をあて，三裂繃帶を以 て充分緊縛繃帶し, 更に最初用ひたる綿花よ り廣く大なる綿花を貼し二度目の緊迫緗帶を なし，更に大なる綿花を貼し，始めて油紙に て被包し縌帶す，而して其の上覤を晒布の袋 （幅廣き紐をつけたるもの）にて被ひ_上方に固 定するを便なりとす. 特に大腿, 下腿, 前膊 等にて切斷上部に於て行はれたる時は, 患肢 は秒々もすれば属曲位を執り創面治澺後早期 義肢裝用に不適となるにより副子を貼するて とあり, 又然らざるも小兒等に於て術後不用 意の體位を執ること或は患肢を動かすことを 防ぐ曘め副子を貼する要あるととあり．

上.述繃帶法に上り，外部繃帶面に血液滲出 し着色せらるることは始どなきも稀に污染せ らることあり, 其の場合には繃帶必副子女全 然解かず，更に大なる綿花及び油紙を斯し䏆 迫繃帶を行方.

上.速繃帶方法は, 余等十數年前九州穷大, 大學院學生在學中，住时敎授の呚室に於て切 斷術のみならず，四肢の大手術には，常に行 はれ居られたる所にして，出血は停止し，创 傷化膿絕無なるにより余等は常に此方法を取 りたるも，現今劣ほ徒に「ガーゼ」綰花を厚く し，單層繃帶を行ふ者も見受けらるるが，斯 くては㥀迫紧迫も充分ならず, 從て出血停此 女不充分にして且化膿に陷り易きにより，紊 知の方法ならむも，特に竝に記諓するてとと せり。

\section{外傷或は化膿性炎症の場合の手術方法}

1) 外傷の場合.

出爽得る限り, 患肢を少しなりとも長く多 く保你せしむる爲め，損傷の狀沇により，皮 临のとり方に注意し或は外側より或は內側よ りとることあるも此むを得ざる所なるも，此 際にも皮辨縫合には，特に注意を拂ひよく創 面を適合せしむるを要す。

2）化膿性炎症の場合.

炎症が切斷せんとする部迄, 波及せる時或 は波及を思はしむる場合，特に「ガス・フレグ モーネ」其の他一般化膿症狀の著しき時は, 皮膚，軟部は輪切にし，骨も略ば其の高さ に於て切斷し，骨膜を除去し，神經，血管の 處置は通常方式によるも，努めて軟部をかき まわさざる樣にし, 筋膜皮膚の縫合は, 全然 行はず制腐劑を用ひ, 三厤繃帶を行ふ, 此際 余は好んで「クロール劑を用ひ，必要に應じ 1 日 3 回位交換す，之により「ガス・フレグモ 一齐の場合にも, 炎症は大抵网 3 日にて消 退し，㓣面は炏第に周圍上り縮小し來り皮虚 も輸狀に近づき來るにより，適當なる時期に 更に整形手術を行ふを可とす，而加女其の際 は具の一部を僅に切除する位にて，極めて簡 單に行はるるを常とす。

\section{術啳の處置}

1) 繃帶交換.

通常術後 5 日目に, 澱密なる防腐的處置の 下に，第 1 包繃帶交換を行ひ，「タンポン・ガ 一ゼ」を少しく引き出し，其の出でたる部を 剪除し，手術直後と同榚，三㲊椞迫繃帶老行 ふ心, 而して大抵術後7-10 日に「タンポン・ガ 
一ゼ」全部を除去し，其の部に「ガーゼ」小片 を貼し，三愿縌帶を施す，其の後每日或は隔 日に繃帶交換を行へば，多くは 2 週間万至 2 週間半にて創面全く治掊す。

2). 拢 綵.

拔絲は術後 10 日頃行ふを常とす.

3）㓣面治癒後の注意

斯くして創面治澺すれば，直に義肢の「モ デル」を取っ、此際注意すべきは, 創面治意後 も義肢出來裝䏚の㭙まで, 切斷端部をかなり
强く是迫繃帶し置き, 亦場合によりては副木 を貼し置くこと，特に必要にして若し之を怠 れば，斷端部に刺度の浮腫を來たし，義肢假 合せの際或は義肢完製裝用の際に\&適合惡 く，斷端の適當なる早期萎縮も遲れ，義肢裝 用不便にして從て自由步行迄長時日を要する ものにして, 特に下腿下 3 分の 1 部に於て切 斷し滕關節迄の義肢を裝用せしむる場合には 充分なる, 後聇迫縌帶の處置を要す. 